\title{
Mismatching and job tasks in Germany - rising over-qualification through polarization?
}

\author{
Daniela Rohrbach-Schmidt and Michael Tiemann * \\ Department of Sociology and Economics of Vocational Education and Training, \\ Federal Institute for Vocational Education and Training, Bonn
}

\begin{abstract}
The paper looks for evidence on whether there is a rise in over-qualification caused by changing skill demand, i.e. a decline of middling jobs, in Germany. We use the BIBB/IAB and BIBB/BAuA Employment Surveys 1979, 1985/86, $1991 / 92,1998 / 1999$ and 2005/2006 to compute measures of person-to-job matching. Firstly, we explore their trends over time. Secondly, we analyze whether trends in over-qualification are related to changes in workers' job tasks. The paper thus contributes to the literature by providing in-depth figures on the incidence of qualification- and skill-based mismatching in Germany within the last three decades. Secondly, we add to the literature by linking the «task-based approach» to the debate on mismatching in Germany.
\end{abstract}

Keywords: over-qualification, job tasks, polarization in employment

\section{Introduction}

Recent analyses with the BIBB/BAuA Employment Survey 2005/2006 (RohrbachSchmidt \& Tiemann, forthcoming) demonstrate that - as in other industrialized countries - mismatching, i.e. the missing correspondence between the skills of a jobholder and the skill requirements of his job - is a relevant phenomenon in the German labor market. Depending on the definition of over- and under-qualification up to forty percent of the German labor force are mismatched regarding their formal or skill requirements, or both. As Green and McIntosh (2007) show for the UK, workers in Germany can be over- or under-qualified in terms of formal qualifications, even though their skills or abilities are appropriate to the jobs they do. There are also workers perfectly matched as regards formal requirements, who nevertheless feel under- or over-challenged by their jobs' skill requirements. Random-intercept models with worker, job and occupation characteristics reveal that beyond worker char-

\footnotetext{
* Corresponding author. Federal Institute for Vocational Education and Training, Robert-SchumanPlatz 3, D-53175 Bonn. Phone: 0049-228-107-1235. E-mail: tiemann@bibb.de. This research is part of the BIBB project «Skill demand change» in the research infrastructure stream «BIBB/BAuA Employment Survey at the Federal Institute of Vocational Education and Training. We thank participants of the BIBB/IAB-Task-Workshop 2010 in Nuremberg and two anonymous reviewers for excellent suggestions.
} 
acteristics, i.e. human capital compensation (heterogeneous ability) and career mobility rationalities, job characteristics such as job tasks at the worker- and the occupation-level have a share in explaining mismatching and its real or apparent wage penalties. ${ }^{1}$

In this paper, we study the link between polarization and over-qualification using over-time data for nearly 30 years, namely the repeated cross-sections of the BIBB/ IAB- and BIBB/BAuA Employment Surveys 1979, 1985/86, 1991/1992, 1998/1999 and $2005 / 2006$. We aim at analyzing whether there is an increase in over-qualification in Germany as it seems to be the case in other European countries such as Sweden and the UK (Korpi \& Tåhlin, 2009; Green, 2006), and whether an increase in the last decades is linked to changes in job tasks and polarization in employment.

\section{Over-qualification and polarization}

The existence of relevant proportions of each nation's labor force being mismatched constitutes a challenge to classical human capital theory (HCT). To be consistent, either mismatching does not exist substantially and the above results are due to unobserved heterogeneity of workers (by measurement error or missing controls such as abilities or skills in wage equations, e.g. see Green \& McIntosh, 2007), or the observed skill gaps are real but persist only for a short time (Sichermann \& Galor, 1990). In other words, either over-qualified (under-qualified) workers are in fact less (more) able than others with similar qualifications (and thus they are in appropriate jobs as regards their skills) or mismatching is only temporal and part of a human capital investment strategy.

Job competition and assignment models assume mismatching to be at least to some extent a real phenomenon in labor markets (Thurow, 1973; Sattinger, 1993). In these models skill requirements and thus wages are strongly determined by the (characteristics of the) job, not the qualification of the worker (alone). It is assumed that not only workers might be more or less able than others, but also that jobs held by over- or undereducated workers might in fact have higher (or lower) skill requirements than observable by schooling levels. Then, for a given job opportunity the allocation of a specific individual is according to his relative position in the job queue which is itself determined by the value of his trainability signaled to the employer by his schooling and experience (Spence, 1973; Sørensen \& Kalleberg, 1981; Kalleberg, 1996). Skills that are relevant for the job as such, to a large extent are acquired by on-the-job training. From this perspective, educational over-investment may result from an over- or undersupply of qualifications in the market. Thus previously adequately-matched workers could happen to be «bumped down» in the labor market and become undereducated, e.g. when hiring standards change over-educated

1 Our wage regressions reveal the pattern in the decomposed coefficients of education into required (RE), over- and under-qualification (OE, UE) originated in the work of Duncan and Hoffman (1981) that is usually reported in the literature across different time points and countries (Rubb, 2003; Hartog, 2000): $\mathrm{OE}>0, \mathrm{UE}<0 ;|\mathrm{UE}|<\mathrm{RE}>\mathrm{OE}$. 
workers allocate into lower-level occupations and thus raise the mean educational level within these occupations (McGuinness, 2006: 388).

Studies for the US (Autor, Katz \& Kearney, 2006), Great Britain (Goos \& Manning, 2007) and some European countries (Goos, Manning et al., 2009) suggest that since the 1990s instead of upgrading the relative demand trends for skills are in fact better described as polarization, i.e. relative declines in middling jobs and relative increases of high- and low-skill jobs. From the «task approach» (Autor, Levy et al., 2003, hereafter ALM) these trends are explained mainly by computerization: computerization would replace human labor in jobs where workers perform routine tasks so that these typically medium-skilled jobs would see a decline in demand (routinization hypothesis). In contrast, technology (as yet) would be complementary to analytic and interactive non-routine job tasks typically performed by high-skilled workers which would lead to a rise in their relative demand. Lastly, in that low-skilled non-routine manual tasks such as truck driving or cleaning are not directly affected by computerization their relative demand is assumed to be increasing as well.

Against that background, in their paper on polarization trends in Britain, Goos and Manning (2007) formulate the idea that due to polarization, i.e. a decrease in middling jobs such as craft, clerical, trade- and plant-related occupations (also see Goos et al., 2009), some educated workers would have been forced into jobs for which their qualifications are unnecessary, and where the minimum educational standards are raised due to more credential-oriented selection procedures by employers (Goos \& Manning, 2007: 128). They present evidence in favor for this assumption (especially as regards sales and elementary occupations) using the UK Social Change and Economic Life Initiative (SCELI) survey 1986 and the 2001 Skills Survey. From this, and similar employment polarization trends for Germany (Spitz-Oener, 2006; Antonczyk et al., 2010)² one would assume a positive correlation of middling occupations and over-qualification in our data.

In our paper we test whether workers in jobs characterized by routine tasks have higher odds of being mismatched than workers in jobs intensive in analytic and interactive non-routine job tasks. Yet, we do not have a prior hypothesis on whether and how jobs intensive in non-routine manual tasks are related to over-qualification. On the one hand, in that they might not be heavily affected by computerization (and off-shoring) they do not see an increase in over-qualification. On the other hand, through displacement these jobs might be more and more performed by formally over-qualified middle-skilled workers.

2 Antonczyk et al. (2009) report quite different trends for 1999 to 2006 in Germany. Instead of an increase in all kinds of non-routine tasks and a decrease of manual and cognitive routine tasks, the authors find a large decrease in non-routine manual tasks, an increase of routine cognitive tasks, and a constancy of non-routine interactive tasks (ibid., p. 9). Our results indicate that at least to some extent this is due to changes in measurement (see section 3 and 4). 


\section{Data and methods}

We use the $\mathrm{BIBB} / \mathrm{IAB}$ and $\mathrm{BIBB} / \mathrm{BAuA}$ labor force cross-sections on qualification and working conditions in Germany from 1979, 1985/86, 1991/92 and 1998/99 and $2005 / 2006 .{ }^{3}$ The study population is people belonging to the labor force (defined as having a paid work) aged 15 and over, with a regular working time of at least ten hours per week. We restrict these samples to male full-time workers (i.e. workers with more than 29 working hours per week) aged 25 to 65 German nationals working in West Germany, leading to a total sample size of 64,999.

To measure over-qualification, we rely on respondents' assessment (yes/no) of whether the current activity could also be performed by workers with a lower-level qualification ${ }^{4}$ (over-qualification). For respondents with only a general education degree (e.g. Abitur) this also includes lower degrees from general education institutions (e.g. Hauptschulabschluss, or no degree at all). This measure was not surveyed in 2005/2006, however. In the 1998/1999 and the 2005/2006 wave, the data include a measure for workers' subjective assessment of whether they generally feel being up to, overstrained or under-challenged by the requirements of their current job against their skills (over-skilling). Former research shows that these types of mismatching are only weakly correlated (Green \& McIntosh, 2007; Rohrbach-Schmidt $\&$ Tiemann, forthcoming): workers can be over- or under-qualified in terms of formal qualifications, even though their skills or abilities are in fact appropriate for the jobs that they do. Using both measures of mismatch gives a deeper insight into what mismatch actually means.

As regards workers heterogeneity in over-qualification, the data allow considering age groups, and highest educational attainment (reclassified in ISCED-97, levels $B$ indicating specific human capital qualifications and virtual years of education). In addition, we examine the role of job characteristics in over-qualification. We use firm size and task measures for non-routine analytic, non-routine interactive, routine manual, routine cognitive, and non-routine manual tasks, each ranging from zero to hundred. ${ }^{5}$ In contrast to Spitz-Oener (2006) and Antonczyk et al. (2009), our assignments of activities to task groups are initially based on a factor analysis solution which we ran with the 17 items in the 2005/2006 data. In the cumulated file, only

3 The first four surveys were realized in cooperation with the Institute of Employment Research (Institut für Arbeitsmarkt- und Berufsforschung, IAB). Since the 2005/06 survey the Federal Institute for Vocational Education and Training (Bundesinstitut für Berufsbildung, BIBB) cooperates with the Federal Institute for Occupational Safety and Health (Bundesanstalt für Arbeitsschutz und Arbeitsmedizin, BAuA). Information on data access is provided by the Research Data Centre at the Federal Institute for Vocational Education and Training (BIBB-FDZ).

4 Respondents were asked: «Could your job also be performed by someone with a lower qualification?»

5 As in Spitz-Oener (2006) single tasks are defined as the number of activities performed by worker $\mathrm{i}$ in one category $\mathrm{j}$ in cross-section $\mathrm{t}$ divided by the total number of activities in one category $\mathrm{j}$ in crosssection $\mathrm{t}$, times hundred. The question posed was whether (in 2006: how often) the following activities (random order) occur at work - yes / no (2006: frequently, sometimes or never). The index is the worker's sum of point values (yes / frequently $=1$, no / sometimes, never $=0$ ) divided by the total number of activities in the respective task group. For a list of the activities see Table A1. 
those single task items were considered that are available in all waves, which reduces the total number of available items to ten (the categorization of single job activities in task groups can be found in table A1 in the appendix). While the single items for the non-routine interactive and the routine manual index were maintained, there remained only two single items for non-routine analytic, and one item each for routine cognitive and non-routine manual tasks. Moreover, in that for some items question wording and thus content changed, the factors for the cumulated file changed as well. As far as we can assess our assignments deviate from those reported elsewhere due to the different items available in the data used by Spitz-Oener 2006 (1979-1999) and Antonczyk et al. (2009; 1999 and 2006, see columns 4 and 5 in table A1). As our results suggest, trends in tasks must be interpreted against changes in the questionnaire (see section 4).

We exploit mixed models (Rabe-Hesketh \& Skrondal, 2008) with workers «nested» in 54 occupations («Berufsfelder», cf. Tiemann, Schade et al., 2008) trying to explain the probability of being over-qualified by job tasks at the worker level. Secondly, to capture trends in the correlation between tasks and over-qualification, we aggregated mean over-qualification, tasks measures and years of education at the occupation-level so that we have a small panel of repeated measures $(t=5)$ for 2 -digit occupational codes $(i=54)$. This allows for estimating fixed effects models of mean over-qualification in occupation $i$.

\section{Results}

Table 1 shows the trends in both over-qualification and over-skilling across waves.

Table 1: Trends in over-qualification and over-skilling across waves

\begin{tabular}{ccccc}
\cline { 2 - 5 } & \multicolumn{2}{c}{ Over-qualification } & \multicolumn{2}{c}{ Over-skilling } \\
\cline { 2 - 5 } & Absolute & Percent & Absolute & Percent \\
\hline 1979 & 3,881 & 24.4 & n.av. & \\
$1985 / 1986$ & 1,027 & 15.2 & n.av. & \\
$1991 / 1992$ & 2,315 & 17.5 & n.av. & \\
$1998 / 1999$ & 4,333 & 34.3 & 789 & 6.0 \\
$2005 / 2006$ & n.av. & & 897 & 12.1 \\
\hline
\end{tabular}

Notes: Study population is restricted to male West-German full-time workers aged 25-65. Source: BIBB/IAB - BIBB/ BAuA Employment Surveys 1979-2006, weighted values, own calculations.

The proportion of workers stating that their current job could also be performed by workers with a lower-level qualification (over-qualification) has declined from 1979 to $1985 / 1986^{6}$ and then increased until $1998 / 1999$ within the population of male West-German full-time workers aged 25 to 65 . Similarly, from 1998/99 to 2005/2006

6 The striking decrease in over-qualification from 1979 to 1985/1986 might be explained by the high share of formally unqualified employees in the workforce until the mid-seventies. Only then, as a consequence of the German «Bildungsexpansion» the share of qualified workers grew (Geißler, 2011). 
the proportion of workers who state that they generally feel under-challenged by the requirements of their current job against their skills (over-skilling) has doubled from six to twelve percent.

The increase in over-qualification and over-skilling is valid for all qualification levels (see table 2). There are particularly large relative increases in over-qualification for workers with the highest qualifications (5A and 5B) and with an apprenticeship training (3B). At each time point, however, it is workers with only lower general degrees and no qualifying vocational degree (ISCED 2A, $2 \mathrm{~B}$ or $3 \mathrm{~A}$ ) that have the highest rates of over-qualification. ${ }^{7}$ Over-qualified workers at all time points have attained years of education below average (see last column).

Contrary to over-qualification, it is especially $2 \mathrm{~B}$ and $3 \mathrm{~B}$ qualifications that witnessed an above average increase of over-skilling. Except the lower rates of overqualification for university graduates $(5 \mathrm{~A})$ the level of over-skilling does not strongly vary between ISCED-97 groups (around 13\%).

Table 2: Trends in over-qualification and over-skilling by highest level of education across waves (case numbers of education groups in total study population in parentheses)

\begin{tabular}{|c|c|c|c|c|c|c|c|c|c|}
\hline ISCED & $<3 B^{*}$ & $0 / 2 \mathrm{~A}$ & $2 \mathrm{~B}$ & $3 \mathrm{~A}$ & 3B & 4 & $\mathbf{5 A}$ & $5 B$ & $\begin{array}{l}\text { Mean years } \\
\text { of education } \\
\text { [all workers] }\end{array}$ \\
\hline \multicolumn{10}{|c|}{ Over-qualification } \\
\hline 1979 & $\begin{array}{c}45.8 \\
(2,054)\end{array}$ & $\begin{array}{l}22.7 \\
(143)\end{array}$ & $\begin{array}{c}48.3 \\
(1,819)\end{array}$ & $\begin{array}{l}28.8 \\
(92)\end{array}$ & $\begin{array}{c}23.5 \\
(9,001)\end{array}$ & $\begin{array}{c}13.0 \\
(120)\end{array}$ & $\begin{array}{c}9.2 \\
(1,634)\end{array}$ & $\begin{array}{c}10.8 \\
(3,082)\end{array}$ & $\begin{array}{l}9.3[10.5] \\
n=16,019\end{array}$ \\
\hline $1985 / 86$ & $\begin{array}{c}36.7 \\
(983)\end{array}$ & $\begin{array}{l}26.2 \\
(54)\end{array}$ & $\begin{array}{c}37.9 \\
(874)\end{array}$ & $\begin{array}{l}27.2 \\
(55)\end{array}$ & $\begin{array}{c}16.0 \\
(3,421)\end{array}$ & $\begin{array}{l}4.6 \\
(86)\end{array}$ & $\begin{array}{c}5.1 \\
(986)\end{array}$ & $\begin{array}{c}6.3 \\
(1,296)\end{array}$ & $\begin{array}{l}9.6[11.4] \\
\mathrm{n}=14,978\end{array}$ \\
\hline $1991 / 92$ & $\begin{array}{c}45.0 \\
(1,276)\end{array}$ & $\begin{array}{l}25.9 \\
(87)\end{array}$ & $\begin{array}{c}49.5 \\
(1,096)\end{array}$ & $\begin{array}{l}20.1 \\
(93)\end{array}$ & $\begin{array}{c}18.8 \\
(6,851)\end{array}$ & $\begin{array}{l}13.3 \\
(213)\end{array}$ & $\begin{array}{c}8.7 \\
(2,060)\end{array}$ & $\begin{array}{c}9.2 \\
(2,787)\end{array}$ & $\begin{array}{c}10.2[11.6] \\
\mathrm{n}=13,301\end{array}$ \\
\hline 1998/99 & $\begin{array}{c}60.8 \\
(1,316)\end{array}$ & $\begin{array}{c}48.0 \\
(174)\end{array}$ & $\begin{array}{c}69.3 \\
(910)\end{array}$ & $\begin{array}{l}34.6 \\
(232)\end{array}$ & $\begin{array}{c}36.8 \\
(6,362)\end{array}$ & $\begin{array}{c}24.5 \\
(473)\end{array}$ & $\begin{array}{c}19.9 \\
(2,566)\end{array}$ & $\begin{array}{c}26.9 \\
(1,858)\end{array}$ & $\begin{array}{c}11.1[12.1] \\
\mathrm{n}=13,242\end{array}$ \\
\hline \multicolumn{10}{|c|}{ Over-skilling } \\
\hline 1998/99 & $\begin{array}{c}5.4 \\
(1,447)\end{array}$ & $\begin{array}{c}6.2 \\
(187)\end{array}$ & $\begin{array}{c}4.4 \\
(967)\end{array}$ & $\begin{array}{c}8.9 \\
(243)\end{array}$ & $\begin{array}{c}5.6 \\
(6,710)\end{array}$ & $\begin{array}{c}7.5 \\
(494)\end{array}$ & $\begin{array}{c}6.4 \\
(2,631)\end{array}$ & $\begin{array}{c}6.9 \\
(1,939)\end{array}$ & $\begin{array}{c}12.5[12,1] \\
n=13,216\end{array}$ \\
\hline $2005 / 06$ & $\begin{array}{c}13.6 \\
(384)\end{array}$ & $\begin{array}{l}12.2 \\
(96)\end{array}$ & $\begin{array}{l}13.3 \\
(196)\end{array}$ & $\begin{array}{l}13.2 \\
(80)\end{array}$ & $\begin{array}{c}13.2 \\
(3,576)\end{array}$ & $\begin{array}{c}14.9 \\
(351)\end{array}$ & $\begin{array}{c}8.2 \\
(2,335)\end{array}$ & $\begin{array}{c}14.1 \\
(764)\end{array}$ & $\begin{array}{c}12.2[12.5] \\
n=7,406\end{array}$ \\
\hline
\end{tabular}

Notes: * Workers with no qualifying vocational degree, i.e. with an ISCED 2A, 2B or 3A degree as their highest attainment. Study population is restricted to male West-German full-time workers aged 25-65. Source: BIBB/IAB - BIBB/BAuA Employment Surveys 1979-2006, weighted values, own calculations.

Over the last decades, educational attainment within occupational groups has increased, as well. Table 3 (columns 2-4) shows the change in average years of education in broad occupations. ${ }^{8}$

7 These include high-school graduates as well as students working more than 10 hours a week. Also, persons in volontaries or senior internships are part of this group. So, for the jobs they perform these employees do not see any special qualification as necessary.

8 These broad occupations are aggregations of vocational fields («Berufshauptfelder»). 
Table 3: Trends in highest level of education and over-qualification by occupations

\begin{tabular}{|c|c|c|c|c|c|c|}
\hline & \multicolumn{3}{|c|}{ Years of education } & \multicolumn{3}{|c|}{$\begin{array}{l}\text { Percentage over-qualified } \\
\text { (Percentage employment) }\end{array}$} \\
\hline & $\begin{array}{l}\text { Mean } \\
1979\end{array}$ & $\begin{array}{l}\text { Mean } \\
2006\end{array}$ & Diff. & $\begin{array}{c}\text { Mean } \\
1979\end{array}$ & $\begin{array}{l}\text { Mean } \\
1999\end{array}$ & Diff. \\
\hline \multicolumn{7}{|l|}{ Occupation (bhf88) } \\
\hline Primary production jobs & 8.84 & 11.06 & 2.22 & $\begin{array}{l}.30 \\
(.06)\end{array}$ & $\begin{array}{l}.48 \\
(.03)\end{array}$ & $\begin{array}{l}.18 \\
(-.03)\end{array}$ \\
\hline Processing, metal working, repairing jobs & 9.48 & 10.88 & 1.29 & $\begin{array}{l}.25 \\
(.26)\end{array}$ & $\begin{array}{l}.32 \\
(.19)\end{array}$ & $\begin{array}{l}.07 \\
(-.07)\end{array}$ \\
\hline Operating / servicing machines & 9.16 & 10.60 & 1.44 & $\begin{array}{l}.35 \\
(.09)\end{array}$ & $\begin{array}{l}.43 \\
(.12)\end{array}$ & $\begin{array}{l}.08 \\
(.03)\end{array}$ \\
\hline Trade in goods, sales & 10.58 & 12.58 & 2.00 & $\begin{array}{l}.25 \\
(.07)\end{array}$ & $\begin{array}{l}.49 \\
(.06)\end{array}$ & $\begin{array}{l}.24 \\
(-.01)\end{array}$ \\
\hline $\begin{array}{l}\text { Jobs in transport, storage, shipping, } \\
\text { security }\end{array}$ & 9.24 & 11.11 & 1.87 & $\begin{array}{l}.40 \\
(.11)\end{array}$ & $\begin{array}{l}.53 \\
(.12)\end{array}$ & $\begin{array}{l}.13 \\
(.01)\end{array}$ \\
\hline Jobs in gastronomy, cleaners & 9.81 & 11.15 & 1.34 & $\begin{array}{l}.28 \\
(.03)\end{array}$ & $\begin{array}{l}.47 \\
(.03)\end{array}$ & $\begin{array}{l}.19 \\
(.00)\end{array}$ \\
\hline Clerks, merchants & 11.39 & 13.73 & 2.34 & $\begin{array}{l}.19 \\
(.15)\end{array}$ & $\begin{array}{l}.29 \\
(.12)\end{array}$ & $\begin{array}{l}.10 \\
(-.03)\end{array}$ \\
\hline Technicians, natural scientists & 12.22 & 14.22 & 2.00 & .11 & $\begin{array}{l}.22 \\
(.16)\end{array}$ & $\begin{array}{l}.11 \\
(.05)\end{array}$ \\
\hline Layer, manager, economists & 13.05 & 14.63 & 1.59 & $\begin{array}{l}.12 \\
(.04)\end{array}$ & $\begin{array}{l}.28 \\
(.07)\end{array}$ & $\begin{array}{l}.16 \\
(.03)\end{array}$ \\
\hline $\begin{array}{l}\text { Artist, media jobs, humanists, social scien- } \\
\text { tists }\end{array}$ & 12.45 & 14.15 & 1.69 & $\begin{array}{l}.13 \\
(.01)\end{array}$ & $\begin{array}{l}.31 \\
(.02)\end{array}$ & $\begin{array}{l}.18 \\
(.01)\end{array}$ \\
\hline Jobs in health care, social care, hygiene & 13.01 & 14.63 & 1.62 & $\begin{array}{l}.13 \\
(.02)\end{array}$ & $\begin{array}{l}.16 \\
(.04)\end{array}$ & $\begin{array}{l}.03 \\
(.02)\end{array}$ \\
\hline Teaching professions & 16.03 & 16.47 & 0.44 & $\begin{array}{l}.07 \\
(.03)\end{array}$ & $\begin{array}{l}.09 \\
(.04)\end{array}$ & $\begin{array}{c}.02 \\
(.01)\end{array}$ \\
\hline
\end{tabular}

Notes: Study population is restricted to male West-German full-time workers aged 25-65. Source: BIBB/IAB - BIBB/ BAuA Employment Surveys 1979-2006, weighted values, own calculations.

All occupations show an increase of more than one year, on average. Big rises above two years plus are observable for primary production jobs, trade and sales jobs, for clerks and merchants as well as for technicians and natural scientists. As also Goos and Manning (2007: 128) argue, this finding might result from increases in skill requirements within jobs or by increases in educational standards because of educational expansion and credentialism. Columns 5-7 report changes in mean proportions of over-qualified workers and relative employment changes (in parentheses) in each occupation. Again one sees increases in over-qualification in all occupations. Reflecting the findings of Goos and Manning (2007), primary production jobs, trade and sales jobs, and jobs in gastronomy, and cleaners are jobs where we find especially large increases in over-qualification. At least for the first two of them, we also find relative employment decreases ${ }^{9}$ over the period, and the figures for relative employment trends show some polarization as described above. The level of over-qual-

9 We are aware that absolute trends would be more meaningful to study. For absolute trends, e.g. see Goos et al. (2010). 
ification was and is comparatively high in operating/servicing machines as well as in jobs in transport, storage, shipping, security. Together, education and over-qualification trends suggest that at least to some extent, educational upgrading within jobs is accompanied by under-utilization of qualification-related skills.

Table 4: Task shifts at the worker-level $\left(n_{\mathrm{i}}=64,972\right)$

\begin{tabular}{lccccc|c}
\hline \multirow{2}{*}{ Task Measure } & Mean & Mean & Mean & Mean & Mean & Change \\
Non-routine cognitive & 1979 & $1985 / 86$ & $1991 / 92$ & $1998 / 99$ & $2005 / 06$ & $1979-2006$ \\
\cline { 2 - 6 } Analytic & 16.5 & 21.7 & 22.4 & 33.3 & 31.4 & 14.9 \\
Interactive & 15.5 & 22.3 & 28.2 & 25.5 & 26.4 & 10.9 \\
Routine & 17.1 & 21.2 & 18.6 & 38.6 & 34.7 & 17.6 \\
$\quad$ Cognitive & 25.8 & 23.3 & 22.5 & 31.2 & 36.6 & 10.8 \\
$\quad$ Manual & 23.5 & 15.8 & 16.1 & 43.7 & 52.4 & 28.9 \\
Non-routine mаnиal & 27.0 & 27.0 & 25.7 & 25.0 & 28.8 & 1.8 \\
\hline
\end{tabular}

Notes: Study population is restricted to male West-German full-time workers aged 25-65. Source: BIBB/IAB - BIBB/ BAuA Employment Surveys 1979-2006, weighted values, own calculations.

Table 4 plots trends in job task. In line with the assumptions, firstly, for all groups of workers, non-routine cognitive job tasks increase over time. On average of all workers, from 1979 to 2006 these tasks rise by 14.9 percentage points. Growth in interactive tasks clearly outweighs growth in analytic tasks. Secondly, as expected from routinization hypothesis, non-routine manual job tasks increase over this period of time. Thirdly, over the whole period, and compared to the growth in non-routine tasks, with only small increases the relative importance of routine manual tasks declines. However, contrary to what is expected from the routinization hypothesis, and contrary to what was found by Spitz-Oener (2006), but in accordance with results presented in Antonczyk et al. (2009) we find that routine cognitive tasks would decline only until the beginning of the 1990s, but afterwards largely increase. Thus, in 2006 , from our results workers would perform more routine tasks than in 1979. Altering the sample selection (e.g. as in Spitz-Oener, 2006, including female workers, workers aged 18 to 24, and excluding agricultural jobs [unweighted], or Antonczyk et al. [2009, «SO-Task-Index»] excluding workers aged 56-65 [unweighted]) does not substantially change our results.

However, we suggest not interpreting this as a substantial result on changes in task demand in Germany, but rather understanding it against methodological changes in the data. We assume that what we have classified as a routine task, namely «measuring, testing, quality control» should - at least for the last two waves - rather be classified as a non-routine task. Firstly, the item(s) wording changed comparatively strongly across waves. While in 1979 there were single items for «measuring length/ weight/temperature» and «testing, controlling (things, information)» (and various others), in 1985/86 and 1991/92 there was only one item for «analyzing, researching, testing, controlling», which from 1998/99 was split into «measuring, testing, quality 
control» and «researching, developing». ${ }^{10}$ Secondly, tasks within the area of measuring and testing might in fact have changed from a mere lower-skilled routine task to a partly higher-skilled non-routine task (at least in Germany) performed by skilled workers in high-tech industries. In fact, this task is highest for workers with a master/technician certificate (not shown). Besides changes in the questionnaire, the data collection mode changed from PAPI to CAPI in 1998/99 and to CATI in 2005/06. It cannot be ruled out that some of the changes in this item as well as in others are merely resulting from these modal changes. ${ }^{11}$ In any case, more research on the reliability and validity of the task measures is needed; differences between waves must be kept in mind when interpreting the results.

Having said this, differences between educational groups are predominantly conforming to the routinization hypothesis (results upon request): Those with no qualifying vocational degree (ISCED 2A, 2B or 3A) as the highest attainment have the lowest levels of non-routine cognitive tasks, while these tasks are most characteristic for jobs of university graduates (ISCED 5A). Over time, it is especially the group of masters and technicians (ISCED 5B) that have witnessed the greatest increase in these tasks. Non-routine manual tasks, in Germany, are slightly more often performed by medium and high-level vocational oriented tracks (i.e. ISCED 3B and 5B) than by workers with no degree. Equally, these three groups do not strongly differ as regards routine manual tasks. Both, routine and non-routine manual tasks are least characteristic for university graduates. The absence of educational differentials in these tasks below the university level might be a sign of some degree of over-qualification.

Are there differences in over-qualification with regards to job tasks? Table 5 plots task means for (not) over-qualified and (not) over-skilled workers averaged over cross-sections.

Table 5: Job tasks by over-qualification and over-skilling

\begin{tabular}{lcccc}
\cline { 2 - 5 } & \multicolumn{2}{c}{ Over-qualification } & \multicolumn{2}{c}{ Over-skilling } \\
\cline { 2 - 5 } & $\begin{array}{c}\text { Over-qualified } \\
\left(\mathrm{n}_{\mathrm{ij}}=11,257\right)\end{array}$ & $\begin{array}{c}\text { Not over-qualified } \\
\left(\mathrm{n}_{\mathrm{j}}=37,217\right)\end{array}$ & $\begin{array}{c}\text { Over-skilled } \\
\left(\mathrm{n}_{\mathrm{j} j}=1,751\right)\end{array}$ & $\begin{array}{c}\text { Not over-skilled } \\
\left(\mathrm{n}_{\mathrm{ij}}=18,840\right)\end{array}$ \\
\hline Non-routine cognitive & 16.9 & 25.4 & 30.0 & 32.9 \\
Analytic & 14.2 & 25.1 & 23.7 & 26.0 \\
Interactive & 18.7 & 25.6 & 34.1 & 37.5 \\
Routine & 25.7 & $25.8^{*}$ & 35.6 & 32.9 \\
Cognitive & 22.6 & 26.6 & 48.5 & $46.6^{*}$ \\
Manual & 27.2 & 25.4 & 29.1 & 26.1 \\
Non-routine manual & 17.0 & 17.8 & 24.3 & 25.5 \\
\hline
\end{tabular}

Notes: * Difference is not statistically significant at the $p<=.05$ or below level. Study population is restricted to male West-German fulltime workers aged 25-65. Source: BIBB/IAB - BIBB/BAuA Employment Surveys 1979-2006, weighted values, own calculations.

10 In our cumulated file «researching and developing» nevertheless is a single item also for waves 1985/86 and 1991/92. In both years, the item was coded as 1 if respondents claim to perform «analyzing, researching, testing, controlling» and «making plans/constructions, designing, drawing» (which is not available in later waves).

11 Similarly, we assume that the peak in non-routine manual jobs and the decline afterwards might be connected with these changes as well. 
In fact, as expected from routinization hypothesis, over-qualified and over-skilled workers less often perform non-routine analytical and interactive tasks than matched and under-qualified (-skilled) workers (statistically significant). Differences in means are especially large for over-qualification. Conform to our expectations their jobs are more intense in routine manual tasks. Again, the picture of routine cognitive tasks is not conforming to our expectations - with higher means for not over-qualified workers. Differences in non-routine manual tasks are relatively small but nevertheless statistically significant. Contrary to the idea of displacement by educated workers non-routine manual tasks are performed by workers who are not over-qualified and not over-skilled more often.

Next, we regress the probability of being overqualified on worker variables within a random-intercept logistic regression model with workers «nested» in occupations. We use these mixed models instead of simple one-stage models (i.e. logistic regression), because we find sizeable proportions of total variance resulting from differences in over-qualification between occupations (ICC=.181). To account for possible time-trends, we include direct and indirect effects of the survey years in our models. ${ }^{12}$ Table 6 reports the results.

Table 6: Random-intercept model of over-qualification

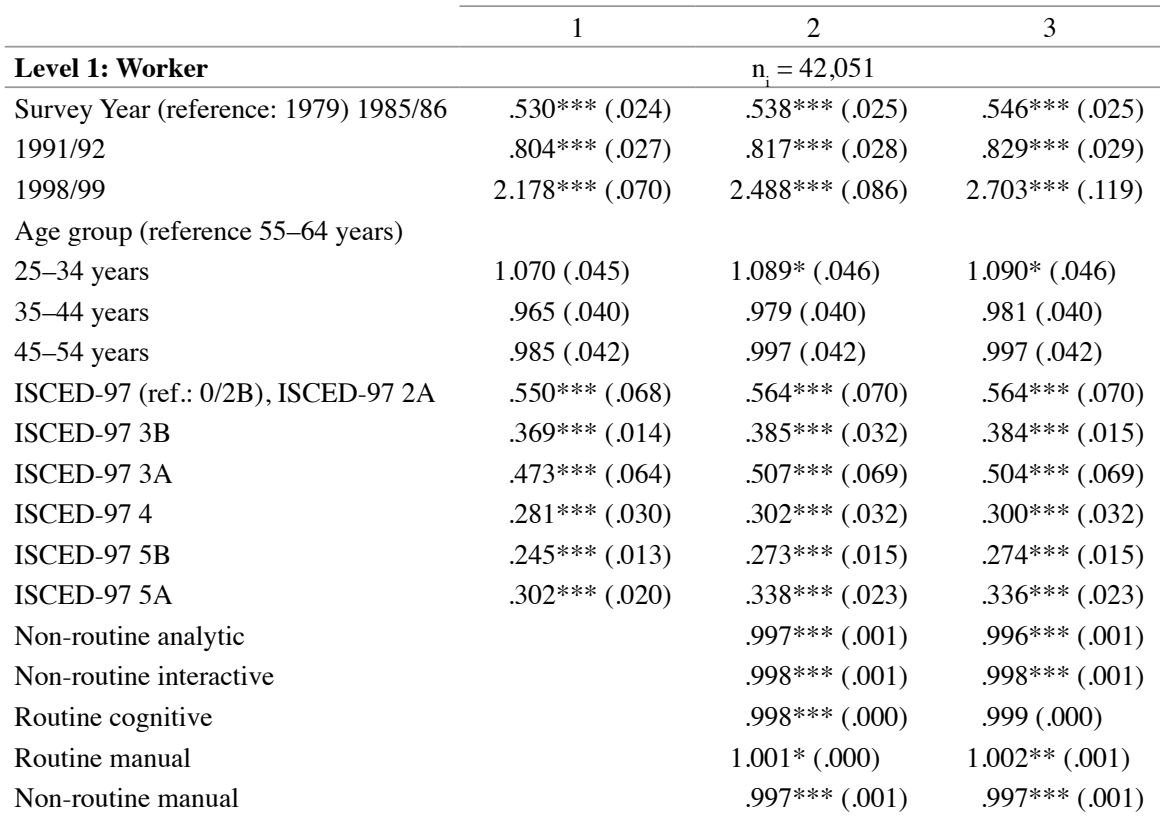

12 Comparing (unstandardized) effect sizes from separate models for each cross-section, results do not differ largely from the pooled analysis; however, changes in coefficients for single tasks might also be influenced by changes in measurement, so we decided not to report them here. Results are nevertheless available on request. 


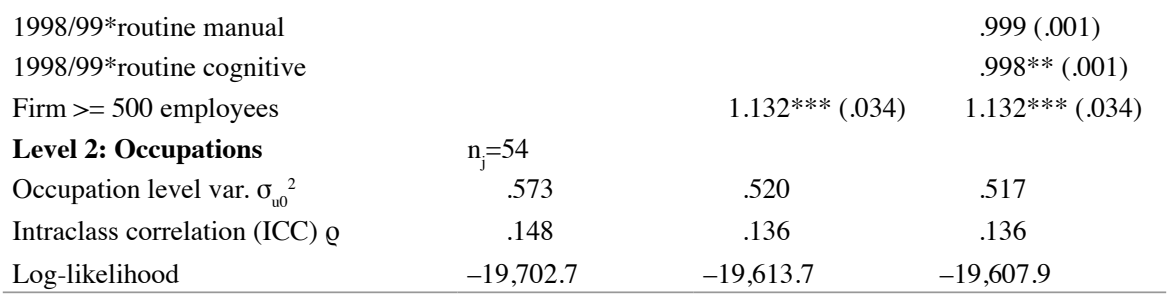

Notes: Mean observations per group: 779. Intercept-only model: $\sigma^{2}=.729$ (.147), ICC $=.181$, LL: $-20,818.8$. Study population is restricted to male West-German full-time employees aged 25-65. Source: BIBB/IAB - BIBB/BAuA Employment Surveys 1979-1998/1999, own calculations.

In model 1, year dummies, age groups and education variables are included. Thus, in $1998 / 1999$ the probability of being over-qualified is more than twice as high as in 1979. Compared to those workers with no or only lowest general education (i.e. degrees from Sonder- or Haupt-/Volksschule, or a pre-vocational training year), all other education groups have lower odds of stating that their job could also be performed by someone with a lower qualification. Within each level, A-qualifications (general education tracks) perform a bit worse in preventing from over-qualification than B-qualifications (vocationally oriented tracks). Coefficients for ISCED-levels demonstrate the specificity of the German educational system; in comparison with other countries, vocational oriented tracks in the upper-secondary and tertiary sector (e.g. apprenticeships in the dual system, master/technicians degrees) perform comparatively well as compared to general tracks at both levels (Abitur and university degrees). Age groups in model 1 have no effects; the weakly higher odds of young workers in models 2 and 3 speak in favor for the assumption that over-qualification to some extent might be a temporal phenomenon within occupational mobility processes.

Model 2 with job characteristics as covariates demonstrates that job tasks in fact have an independent share in the over-qualification variance. Moreover, to some extent results for single coefficients speak in favor for the supply-demand explanation of mismatching: the more a worker is performing a job that is characterized by routine manual tasks, the higher is the risk of being over-qualified..$^{13}$ On the other hand, jobs intensive in non-routine tasks but also in routine cognitive tasks prevent from over-qualification. As model 3 shows, the correlation between routine manual tasks and over-qualification is not reinforced in the last panel and that the main effect of cognitive routine tasks traces back to the 1998/99 data. Moreover, both models demonstrate that being employed in large firms is related to higher odds of being over-qualified.

13 Interestingly, in over-skilling models routine manual tasks have relatively strong negative effects. Possibly, routine manual workers feel less under-challenged because of the repetitive, physically demanding character of their jobs that are thus very exhausting. In line with this assumption, we find that workers who frequently or always are «carrying heavy stocks», «working in a standing position», and «work with noise» have significantly higher means in routine manual tasks than other workers. In general, as it is also found in analyses with the 2005/06 file only (Rohrbach-Schmidt \& Tiemann, forthcoming) running same models demonstrates that both measures of over-qualification relate to different concepts of mismatching. 
In order to capture trends in the correlation between tasks and over-qualification, we aggregated our data at the occupation-level so that we have a small panel of repeated measures for 2-digit occupational codes $(i=54)$. This allows for estimating fixed effects models of mean over-qualification in occupation $i$ and with $t=4$.

Table 7: Fixed effects model of over-qualification (occupation-level)

\begin{tabular}{lccc} 
& 1 & 2 & 3 \\
\hline Non-routine analytic & & -.0006 & -.0009 \\
Non-routine interactive & & $.0026^{* *}$ & $.0020^{*}$ \\
Routine cognitive & & $.0029 * * *$ & $.0029^{* * *}$ \\
Routine manual & & $.0018^{*}$ & $.0019^{*}$ \\
Non-routine manual & & .0014 & .0014 \\
Years of education & & & .0196 \\
Constant & $.238^{* * *}$ & .0508 & $-.1576^{* *}$ \\
& & & \\
$\mathrm{R}^{2}$ within & .000 & .495 & .502 \\
$\mathrm{R}^{2}$ between & .000 & .096 & .322 \\
$\sigma_{\mathrm{u} 0}$ & .151 & .175 & .197 \\
$\sigma_{\mathrm{e}}$ & .112 & .100 & .080 \\
$\mathrm{Rho}$ & .646 & .825 & .857 \\
\hline
\end{tabular}

Notes: $N_{i}=216 / n_{i}=54$. Study population is restricted to male West-German full-time employees aged $25-65$. Source: BIBB/IAB - BIBB/BAuA Employment Surveys 1979-1998/99, own calculations

Results are printed in table 7 . The average percent of over-qualification is 0.238 and differences in over-qualification to 65 percent result from differences within occupations over time (model 1). As model 2 reveals some job tasks are good predictors of over-qualification at the occupation level. Parallel to the findings for the models presented above, the more the occupation is characterized by routine tasks the higher is the proportion of over-qualification. In addition, the model estimates significant positive effects on over-qualification from non-routine interactive and routine cognitive tasks. The picture is not changed when we include average years of education in model 3. Thus, even when skill supply is controlled for, occupations characterized by routine job tasks significantly increase over-qualification. The mean qualification level of occupations itself is not significantly related to over-qualification but introducing it to the model contributes to explain a substantial part of the between occupation variance.

Overall, based on our cross-sectional and panel data models we can't reject the hypothesis that due to polarization in employment, over-qualification in Germany has increased. Job tasks do in fact have a share in explaining over-qualification trends within occupations over time. 


\section{Conclusion}

The aim of the paper is to study trends in over-qualification in Germany over time, and its relation to changes in job tasks, respectively. To this end, we use over-time data for the time span of nearly 30 years, i.e. repeated cross-sections of the BIBB/ IAB - BIBB/BAuA Employment Surveys 1979, 1985/86, 1991/1992, 1998/1999 and 2005/2006.

Our analyses show that there is substantial upgrading in educational attainment within occupational groups over time. Secondly, we see some polarization in employment throughout the observed period. Both processes are accompanied by an increase in over-qualification in Germany from the mid 1980s on: The proportion of workers stating that their current job could also be performed by workers with a lower-level qualification (over-qualification) has declined from 1979 to 1985/1986 and then increased until 1998/1999 within the population of male West-German fulltime workers aged 25 to 65 . Similarly, from $1998 / 99$ to 2005/2006 the proportion of workers who state that they generally feel under-challenged by the requirements of their current job against their skills has doubled from six to twelve percent.

Random-coefficient models with workers «nested» in occupations and fixed effects models with repeated measures for 2-digit occupational codes, speak in favor of the supply-demand explanation of over-qualification. Overall, we can't reject the hypothesis that due to polarization in employment, over-qualification in Germany has increased. Yet, more robust tests of the over-qualification hypothesis would include the analysis of career data with panel information on tasks and over-qualification. So far, these data are not available in Germany.

Exploiting BIBB/IAB and BIBB/BAuA surveys 1979 to 2006 for longitudinal analysis, it should be kept in mind that there have been several changes in the questionnaire and data collection mode. Especially coefficients in job task measures seem to be sensible to item changes. Therefore, researchers should make transparent their task classifications at a very detailed level. However, more effort must be spent on the reliability and validity of task measures. And indeed, relying on only the one item battery of tasks does not consider the full potential of the data. One possibility to better the over-time comparability could be to additionally use other skill and job activity items surveyed in each wave. An overall conclusion of our paper is that one important challenge of the task-approach is measurement.

\section{References}

Antonczyk, D.; Fitzenberger, B. \& Leuschner, U. (2009). Can a task-based approach explain the recent changes in the German wage structure? Journal of Economics and Statistics, 229(2+3):214-238

Antonczyk, D.; DeLeire, T. \& Fitzenberger, B. (2010). Polarization and rising wage inequality: Comparing the U.S. and Germany. IZA Discussion Paper Series, No. 4842. Bonn: IZA

Autor, D. H. \& Handel, M. J. (2009). Putting tasks to the test: human capital, job tasks and wages. NBER Working Paper, No. 15116. Cambridge MA: National Bureau of Economic Research

Autor D. H.; Katz, L. F. \& Kearney, M. S. (2006). The polarization of the US labor market. Cambridge MA: National Bureau of Economic Research 
Autor, D. H.; Levy, F. \& Murnane, R. J. (2003). The skill content of recent technological change: An empirical exploration. Quarterly Journal of Economics 118(4)

Duncan, G. J. \& Hoffman S. D. (1981). The incidence and wage effects of overeducation. Economics of Education Review, 1(1): 75-86

Geißler, R. (2011). Die Sozialstruktur Deutschlands. Wiesbaden, VS Verlag

Goos, M. \& Manning, A. (2007). Lousy and lovely jobs: the rising polarization of work in Britain. The review of economics and statistics, 89(1): 118-133

Goos, M.; Manning, A. \& Salomons, A. (2009). Job polarization in Europe. American Economic Review Papers and Proceedings, Vol. 99, No. 2, May 2009, pp. 58-63

Green, F. (2006). Demanding work. The paradox of job quality in the affluent economy. Princeton NY: Princeton University Press

Green, F. \& McIntosh, S. (2007). Is there a genuine under-utilization of skills amongst the over-qualified? Applied Economics, 39: 427-439

Hartog, J. (2000). Overeducation and earnings. Where are we, where should we go? Economics of Education Review, 19(2): 131-147

Kalleberg, A. L. (ed.) (1996). Organizations in America. Analyzing their structures and human resource practices. Thousand Oaks CA: Sage

Korpi, T. \& Tåhlin, M. (2009). Educational mismatch, wages, and wage growth. Overeducation in Sweden 1974-2000. Labour economics, 16(2): 183-193

McGuinness, S. (2006). Overeducation in the labour market. Journal of economic surveys, 20(3): 387-418

Rabe-Hesketh, S. \& Skrondal, A. (2008). Multilevel and longitudinal modeling using Stata. College Station: Stata Press

Rohrbach-Schmidt, D. \& Tiemann, M. (forthcoming). Qualification and skill-based mismatching in Germany, In: F. Green \& M. Keese: Job tasks, work skills and the labour market. Paris, OECD

Rubb, S. (2003). Overeducation in the labor market. A comment and re-analysis of a meta-analysis. Economics of Education Review, 22(6): 621-629

Sattinger, M. (1993). Assignment models of the distribution of earnings. Journal of economic literature, 31(2): 831-880

Sichermann, N. \& Galor, O. (1990). A theory of career mobility. Journal of Political Economy, 98(1): 169-192

Sørensen, A. B. \& Kalleberg, A. L. (1981). An outline of a theory of the meaning of persons to jobs. In: I. Berg (ed.): Sociological perspectives on labor markets, pp. 49-74. New York, Academic Press

Spence, M. A. (1973). Job market signaling. Quarterly Journal of Economics, 87(3): 355-374

Spitz-Oener, A. (2006). Technical change, job tasks, and rising educational demands. Looking outside the wage structure. Journal of labor economics, 24(2): 235-270

Thurow, L. C. (1973). Generating inequality. New York: Basic Books

Tiemann, M.; Schade, H.-J.; Helmrich, R. et al. (2008). Berufsfeld-Definitionen des BIBB. Wissenschaftliche Diskussionspapiere des Bundesinstitutes für Berufsbildung, Nr. 105. Bonn: BIBB 


\section{Appendix}

Table A1: Categorization of task items to ALM task groups

\begin{tabular}{|c|c|c|c|c|}
\hline Task group & Demand & 1979-2006 & $\begin{array}{l}\text { Antonczyk et al., } 2008 \\
(1998 / 99-2006)\end{array}$ & $\begin{array}{l}\text { Spitz-Oener, 2006 } \\
(1979-1998 / 99)\end{array}$ \\
\hline $\begin{array}{l}\text { Non-routine } \\
\text { cognitive: } \\
\text { analytic }\end{array}$ & increasing & $\begin{array}{l}\text { Q101, Q104 } \\
\left(\text { alpha }_{a n}: .21-.40\right)\end{array}$ & $\begin{array}{l}\text { Q104, (gathering } \\
\text { information, investigat- } \\
\text { ing, documenting, n.av.) }\end{array}$ & $\begin{array}{l}\text { Q101, Q104, (using and } \\
\text { interpreting rules, n.av.) }\end{array}$ \\
\hline Interactive & increasing & $\begin{array}{l}\text { Q095, Q096, Q100 } \\
\left.\text { (alpha }_{\text {int }}: .41-.63\right) \\
\text { alpha }_{\text {nrcog }}: .50-.62\end{array}$ & $\begin{array}{l}\text { Q095, Q096, Q100 } \\
\text { Q101 }\end{array}$ & $\begin{array}{l}\text { Q095, Q096, Q100, } \\
\text { (employing, managing } \\
\text { personnel, n.av. and } \\
\text { negotiating, lobbying, } \\
\text { coordinating, n.av.) }\end{array}$ \\
\hline $\begin{array}{l}\text { Routine: } \\
\text { cognitive }\end{array}$ & falling & Q097 & Q097 & $\begin{array}{l}\text { Q097 (calculating, book } \\
\text { keeping, correcting } \\
\text { texts/data, n.av.) }\end{array}$ \\
\hline Manual & falling & $\begin{array}{l}\text { Q098, Q105 } \\
\left.\text { (alpha }_{\text {rman }}: 13-.49\right) \\
\text { alpha }_{\text {rout }}: .16-.59\end{array}$ & $\begin{array}{l}\text { Q098, Q105, (transport- } \\
\text { ing, stocking, posting, } \\
\text { n.av.) }\end{array}$ & $\begin{array}{l}\text { Q098, (equipping } \\
\text { machines, n.av.) }\end{array}$ \\
\hline $\begin{array}{l}\text { Non-routine } \\
\text { manual }\end{array}$ & $\begin{array}{l}\text { constant/ } \\
\text { increasing }\end{array}$ & $\begin{array}{l}\text { Q099, Q106 } \\
\text { alpha }_{\text {nrman }}: .06-.22\end{array}$ & Q099, Q106 & Q099, Q106 \\
\hline
\end{tabular}

Q095 Training, teaching, tutoring, education

Q096 Advising, informing

Q097 Measuring, testing, quality control (Spitz-Oener, 2006: Measuring length/weight/temperature)

Q098 Operating/supervising, controlling machines, plants, technical processes

Q099 Repairing, patching (in Spitz-Oener, 2006: Repairing or renovating houses, apartments, machines, vehicles, restoring art, monuments)

Q100 Buying, providing, marketing, public relations, bargaining

Q101 Organizing, planning/preparing work processes

Q104 Researching, developing, designing

Q105 Manufacturing, producing of products and goods

Q106 Nursing, serving, healing (in Spitz-Oener, 2006: Serving and accommodating) 